Думенко М. П., к.військ.н. ${ }^{1}$; Прокопенко О. С. ${ }^{2}$ (ORCID 0000-0002-5482-0317)

1 - Головне управління персоналу Генерального штабу Збройних Сил України, Київ;

2 - Центр воєнно-стратегічних досліджень Національного університету оборони України імені Івана Черняховського, Київ.

\title{
Оцінювання військовослужбовців під час формування списку резерву щодо укомплектування підготовленим особовим складом
}

Резюме. У статті розглянуто питання щодо укомплектування збройних сил підготовленим особовим складом використовуючи резерв. Резерв формується на базі рейтингу військовослужбовців у вигляді рейтингового списку. Удосконалено методику формування рейтингового списку.

Ключеві слова: укомплектування збройних сил підготовленим особовим складом; кадровий резерв; оцінювання військовослужбовця; рейтинговий список; список кандидатів до призначення на визначену посаду.

Постановка проблеми. В Україні в умовах особливого періоду під час проведення часткової мобілізації відбулось значне надходження людських ресурсів до збройних сил, їх укомплектування підготовленим особовим складом.

3 цього приводу нагальним постає питання формування військового резерву, тобто певного складу громадян, що пройшли підготовчий відбір (оцінювання) i мають необхідний потенціал для виконання прямих обов'язків на відповідній посаді у встановлені терміни.

Для підвищення прозорості та оперативності у прийнятті кадрових рішень щодо призначення військовослужбовців на посади за аналізом досліджень доцільно використовувати рейтинговий принцип.

Аналіз останніх досліджень i публікацій. Дослідження питань укомплектування посад підготовленим особовим складом завжди посідали провідне місце у сучасних підходах управління персоналом як закордонних, так і вітчизняних збройних силах. У більшості автоматизованих систем управління персоналом закордонного виробництва, однією 3 основних функцій модулів управління талантами $\epsilon$ підбір персоналу (рекрутинг), від спроможності яких залежить якість підбору на посади, що надалі впливає на ефективність виконання посадових обов'язків особовим складом за різною номенклатурою призначення.

Однією 3 вимог під час атестування та визначення рейтингу військовослужбовців $\epsilon$ забезпечення об'єктивності оцінок. У роботі [1] досліджені фактори, які впливають на об'єктивність процесів оцінювання: врахування специфіки посад під час розроблення критеріїв оцінювання службової діяльності особового складу та пріоритетність цих критеріїв; удосконалення керівних документів, що забезпечить ефективне управління кар'єрою, індивідуальний підхід, прозорість та відкритість під час прийняття кадрових рішень; удосконалення спеціального програмного забезпечення оцінювання службової діяльності та формування рейтингу військовослужбовців.

У роботі [2], здійснено аналіз світового досвіду стосовно особливостей формування та використання кадрового резерву у збройних силах провідних країн світу, підходів та етапів підготовки кадрового резерву i технологій управління кар'єрою особового складу. Наводиться перелік процесів, які доцільно автоматизувати завдяки впровадженню інформаційно-аналітичних та ERP-систем управління особовим складом.

У роботі [3] проведено аналіз процесів управління кар'єрою, формування i використання Резерву кандидатів для просування по службі. Узагальнено принципи комплектування збройних сил кадровим ресурсом та порядок відбору кандидатів за рейтинговим принципом, 3 врахуванням особливостей автоматизації зазначених процесів у вітчизняних інформаційноаналітичних системах управління персоналом.

$$
\text { Варіант побудови рейтингу }
$$
військовослужбовців на основі таксономічного аналізу розглянуто у роботі [4], де наводиться алгоритм проведення математичних розрахунків, щодо вирішення завдання 
формування рейтингу методом таксономії, також описані переваги його використання у діючому макеті визначення рейтингу військовослужбовців, реалізованому за допомогою програмного забезпечення СУБД Microsoft Access.

Одним 3 важливих аспектів процедури оцінювання військовослужбовців є виявлення критеріїв, які дають змогу всебічно оцінити кожну особистість, результати його службової діяльності, особисті якості та компетентності. Це пов'язано з осучасненням збройних сил, новими викликами та загрозами, завданнями, що ставляться перед збройними силами. Рекомендації щодо переліку критеріїв оцінки службової діяльності військовослужбовців за типами посад розглянуто колективом авторів у роботі [5].

Аналіз наведених робіт, свідчить про існуючі підходи до порядку оцінювання та формування рейтингу військовослужбовцівкандидатів на посаду у плановому порядку, за результатами комплексного (щорічного) оцінювання, проте не розглядають можливості щодо проведення цієї процедури під час різкого збільшення кадрового ресурсу, на кшталт, проведення заходів 3 часткової мобілізації. У цьому разі, необхідно приділити достатньо уваги об'єктивності проведення зазначених процедур, від яких залежить професіоналізм особового складу та якість виконання посадових обов'язків.

Мета статті. Обгрунтування пропозицій щодо підвищення об'єктивності оцінювання військовослужбовців під час формування списку резерву підготовленим особовим складом.

\section{Викладення основного матеріалу.} Рейтинг - це індивідуальний кількісний показник, який визначає позицію військовослужбовця відносно інших кандидатів у резерві за результатами оцінювання.

Резерв складається в інстанції кожної номенклатури призначення військовослужбовців за всіма типовими посадами та існуючими спеціальностями.

Резерв кандидатів для просування по службі (рейтингові списки кандидатів до призначення на типову посаду) - це формалізований документ, який складається на підставі результатів комплексного (щорічного в особливий період) оцінювання військовослужбовців та визначає перелік типових посад відповідної номенклатури призначення i військовослужбовців, які відібрані для цілеспрямованої підготовки до просування по службі (направлення на навчання) на визначені посади [6].

Комплексне оцінювання здійснюється для визначення відповідності військовослужбовців займаним посадам, створення Резерву і Плану переміщення на посади за результатами оцінювання їх службової діяльності за рік та прийняття рішень щодо просування або переміщення військовослужбовців по службі, або їх звільнення $з$ військової служби [7].

Система оцінювання має базуватися на аналізі відповідності вимог посади та результатів виконання військовослужбовцем функцій за даною посадою, спрямовуватися на розвиток та планування його кар'єри, сприяти можливості розкриття особистісного та кваліфікаційного потенціалу військовослужбовця. У такому разі основною формою роботи 3 кадрами є робота відповідних конкурсних, експертних комісій, спеціально підготовлених експертів та фахівців кадрових органів.

Критеріями оцінювання військовослужбовця $\epsilon$ : результативність та поведінка у процесі діяльності, знання, вміння, навички, досвід (компетентність) та психологічні особистості (особистісні якості та риси характеру).

Розрізняють декілька підходів оцінювання персоналу, переважну більшість яких поділяють на дві складові [8].

До першої групи належать якісні методи, засновані на використанні підходів до вивчення працівників на основі співбесіди, спостереження тощо. До другої - кількісні методи, в основі яких лежать формалізовані підходи на основі анкетування, тестування та iн.

Комбінація кількісних та якісних методів оцінювання військовослужбовців надає найбільший ефект при визначенні кандидатів для просування по службі (об’єктів оцінювання).

Найбільшу увагу під час оцінювання військовослужбовців приділяють оцінці якісних показників. У цьому разі основним підходом є використання методу експертних оцінок [9]. Використання експертних методів передбачає використання фахових спеціалістів, які мають відповідати певним вимогам - вміння узагальнити свій і світовий досвід щодо визначеної області знань; наявність далекоглядності, що стосується певної області знань і практичної діяльності. Однак незначна швидкість отримання результатів за недостатньої статистичної виборці не повною 
мірою гарантує адекватність оцінювання, що цілком залежить від компетенції експертів. Суб'єктивність методу доповнює необхідність за експертів мати висококваліфікованих фахівців. Недоліки доповнює значна трудомісткість процедури збору інформації.

У визначених умовах заслуговує на увагу метод кластерного аналізу, спектр застосування якого на сьогодні посідає провідне місце у наукових дослідженнях різних сфер діяльності [10]: економічній, медичній, військовій, інформаційній, державного управління та ін. Кластерний аналіз - це загальна назва великої кількості обчислювальних процедур, що використовуються під час створення класифікацій. Унаслідок роботи 3 процедурами утворюються “кластери”, або групи дуже схожих об’єктів. Більш точно, кластерний аналіз - це багатовимірна статистична процедура, що виконує збір даних, що містять інформацію про вибірку об'єктів, 3 подальшим їх впорядкуванням в порівняно однорідні групи [11].

Однією 3 причин підвищеного інтересу до кластеризації обгрунтовується іiі побудовою на класифікаціях, що привносять закономірність у наукових дослідженнях. Вона містить основні понятт, що використовуються наукою. Оскільки кластерні методи розглядаються як об'єктивні, легко відтворювані способи створення класифікацій, то вони користуються широкою популярністю.

Використання методів кластерного аналізу і таксономії, доречно застосовувати під час формування рейтингу (рейтингових списків) військовослужбовців кожної номенклатури призначення. Суть зазначених методів полягає у визначенні значення узагальненого показника вагомості для кожного об'єкта (військовослужбовця), який являє собою синтетичну величину “рівнодіючу” всіх критеріїв, що дає змогу лінійно упорядкувати об'єкти (військовослужбовців) за рейтингом. Початковими даними для проведення розрахунків зазначеними методами є чисельні значення оцінки показників додаткових факторів (критеріїв), оцінених за п'ятибальною шкалою оцінювання якості, визначеної у документі [12].

Метод кластерного аналізу був використаний та позитивно себе зарекомендував під час експерименту, щодо визначення рейтингу військовослужбовців у Повітряних Силах Збройних Сил України відповідно до вимог керівних i плануючих документів [14 - 16].

За основу формування рейтингу військовослужбовців пропонувався перелік критеріїв оцінювання службової діяльності військовослужбовців за типами посад (Табл. 1), який був розроблений та науково обгрунтований Військовим інститутом Київського національного університету імені Тараса Шевченка [5].

Сформований рейтинговий список став підставою для підготовки пропозицій Командувачу Повітряних Сил Збройних Сил України щодо прийняття кадрового рішення за кожною вакантною посадою окремо.

Таблиця 1

Критерії оцінки службової діяльності військовослужбовців на посадах керівного складу

\begin{tabular}{|c|c|c|}
\hline №3/II & $\begin{array}{l}\text { Критерії оцінювання } \\
\text { службової діяльності }\end{array}$ & Складові критеріїв (підкритерії) \\
\hline \multirow{9}{*}{1} & \multirow{9}{*}{$\begin{array}{l}\text { Рівень професійних } \\
\text { знань }\end{array}$} & $\begin{array}{l}\text { Знання правового мінімуму та керівних нормативно-правових документів за } \\
\text { напрямами роботи за посадою }\end{array}$ \\
\hline & & $\begin{array}{l}\text { Знання керівних документів, що регламентують роботу щодо проходження } \\
\text { військової служби відповідними категоріями військовослужбовців }\end{array}$ \\
\hline & & $\begin{array}{l}\text { Знання керівних документів, що регламентують роботу щодо трудової } \\
\text { діяльності працівників Збройних Сил України }\end{array}$ \\
\hline & & $\begin{array}{l}\text { Знання керівних документів, що регламентують облік особового складу } \\
\text { Збройних Сил України }\end{array}$ \\
\hline & & $\begin{array}{l}\text { Знання керівних документів, що регламентують правильність ведення } \\
\text { нетаємного діловодства }\end{array}$ \\
\hline & & $\begin{array}{l}\text { Знання керівних документів, що регламентують роботу } 3 \text { атестування } \\
\text { офіцерського складу запасу }\end{array}$ \\
\hline & & $\begin{array}{l}\text { Рівень дотримання в повсякденній діяльності вимог керівних нормативно- } \\
\text { правових документів }\end{array}$ \\
\hline & & Підвищення особистої кваліфікації, рівень професійної підготовки, компетенції \\
\hline & & Оцінка за командирську підготовку \\
\hline \multirow{3}{*}{2} & \multirow{3}{*}{$\begin{array}{l}\text { Рівень професійних } \\
\text { умінь та навичок }\end{array}$} & $\begin{array}{l}\text { Навички аналітичної роботи, уміння прогнозувати перспективи й можливі } \\
\text { проблеми за напрямами роботи за посадою та запобігати їм }\end{array}$ \\
\hline & & $\begin{array}{l}\text { Уміння опрацьовувати статистичний звіт з кадрових питань згідно з Табелем } \\
\text { термінових донесень }\end{array}$ \\
\hline & & Уміння робити аналіз якісного складу військовослужбовців \\
\hline
\end{tabular}




\begin{tabular}{|c|c|c|}
\hline №3/II & $\begin{array}{l}\text { Критерії оцінювання } \\
\text { службової діяльності }\end{array}$ & Складові критеріїв (підкритерії) \\
\hline & & Навички у веденні встановленої звітно-облікової документації \\
\hline & & $\begin{array}{l}\text { Навички у підготовці матеріалів щодо призначення, звільнення, нагородження } \\
\text { військовослужбовців і працівників ЗС }\end{array}$ \\
\hline & & $\begin{array}{l}\text { Навички у роботі, які пов'язані із заповненням, обліком і зберіганням особових } \\
\text { справ (службових карток) } \\
\text { працівників ЗС }\end{array}$ \\
\hline & & $\begin{array}{l}\text { Навички роботи, пов'язаної із вихованням, забезпеченням військової } \\
\text { дисципліни, підтриманням морально-психологічного стану особового складу } \\
\text { відділу, створенням в колективі творчої атмосфери, спрямованої на вчасне i } \\
\text { якісне виконання завдань }\end{array}$ \\
\hline & & $\begin{array}{l}\text { Уміння планувати й здійснювати заходи щодо охорони державної таємниці та } \\
\text { захисту інформації з обмеженим доступом у відділі }\end{array}$ \\
\hline & & Навички виконання посадових обов'язків в особливий період \\
\hline & & Виконання обов'язків начальника відділу під час його відсутності \\
\hline & & Виконання нормативів з дисциплін командирської підготовки \\
\hline \multirow{11}{*}{3} & \multirow{11}{*}{$\begin{array}{l}\text { Виконання посадових } \\
\text { обов'язків }\end{array}$} & Якість планування роботи відділу \\
\hline & & $\begin{array}{l}\text { Рівень знання ділових і професійних якостей офіцерів, працівників Збройних } \\
\text { Силах України }\end{array}$ \\
\hline & & $\begin{array}{l}\text { Рівень організації роботи щодо укладення контрактів про проходження } \\
\text { військової служби в Збройних Силах України }\end{array}$ \\
\hline & & Рівень організації довідкової роботи у відділі \\
\hline & & Рівень організації своєчасного відпрацювання документів \\
\hline & & Рівень забезпечення дотримання законності в роботі відділу \\
\hline & & $\begin{array}{l}\text { Рівень вимогливості щодо дотримання вимог режиму секретності, захисту } \\
\text { таємної інформації та інформації з обмеженим доступом у відділі, виключення } \\
\text { випадків виконання таємних документів на ПЕОМ }\end{array}$ \\
\hline & & Наявність у відділі атмосфери творчого і якісного виконання завдань \\
\hline & & Рівень особистої виконавчої дисципліни \\
\hline & & Дотримання вимог Кодексу честі офіцера \\
\hline & & Надання підлеглим прикладу зразкового виконання військового обов’язку \\
\hline \multirow{2}{*}{4} & \multirow{2}{*}{$\begin{array}{l}\text { Ефективність } \\
\text { управлінської } \\
\text { діяльності }\end{array}$} & $\begin{array}{l}\text { Реальність та обгрунтованість планів за напрямками роботи, відповідність їх } \\
\text { завданням Військового Інституту }\end{array}$ \\
\hline & & $\begin{array}{l}\text { Організація контролю за виконанням планів, заходів щодо корекції планів і } \\
\text { завдань }\end{array}$ \\
\hline \multirow{2}{*}{5} & \multirow{2}{*}{$\begin{array}{l}\text { Професійний } \\
\text { розвиток підлеглих }\end{array}$} & Ефективність підготовки, перепідготовки та підвищення кваліфікації підлеглих \\
\hline & & Мотивація для особового складу щодо праці над собою \\
\hline \multirow{4}{*}{6} & \multirow{4}{*}{$\begin{array}{l}\text { Штабна культура } \\
\text { (культура роботи } \\
3 \text { документами) }\end{array}$} & Якість оформлення проектів наказів, розпоряджень і донесень \\
\hline & & $\begin{array}{l}\text { Якість та своєчасність відпрацювання документів, призначених до виконання } \\
\text { начальником інституту }\end{array}$ \\
\hline & & Якість розроблення та правильність оформлення мобілізаційних документів \\
\hline & & Педантичність та акуратність під час підготовки розпоряджень і донесень \\
\hline \multirow{3}{*}{7} & \multirow{3}{*}{$\begin{array}{l}\text { Уміння } \\
\text { організовувати та } \\
\text { проводити заняття } \\
\text { (наради) }\end{array}$} & $\begin{array}{l}\text { Якість планування (плани проведення занять відпрацьовані навчальні питання } \\
\text { сформульовані чітко) }\end{array}$ \\
\hline & & $\begin{array}{l}\text { Проведення заняття, наради (вільно володіє матеріалом, доповідає чітко, } \\
\text { зрозуміло, підтримує контакт зі слухачами, реагує на запитання та репліки) }\end{array}$ \\
\hline & & $\begin{array}{l}\text { Підбиття підсумків заняття (зроблений висновок, сформульоване завдання, } \\
\text { відмічені досягнення та недоліки) }\end{array}$ \\
\hline \multirow{3}{*}{8} & \multirow{3}{*}{$\begin{array}{l}\text { Зовнішній вигляд та } \\
\text { стройова виправка }\end{array}$} & Бездоганність повсякденного зовнішнього вигляду \\
\hline & & Оцінка за зовнішній вигляд на стройовому огляді \\
\hline & & Оцінка за виконання стройових прийомів на стройовому огляді \\
\hline \multirow{2}{*}{9} & \multirow{2}{*}{$\begin{array}{l}\text { Стан фізичної } \\
\text { підготовленості }\end{array}$} & Рівень швидкісних якостей, сили, спеціальної та загальної витривалості \\
\hline & & Уміння організовувати та проводити заняття з фізичної підготовки \\
\hline
\end{tabular}

Оскільки кожен 3 критеріїв оцінювання несе різний функціональний зміст, визначення інтегральної оцінки кандидата за кожним 3 кластерів вирішується за допомогою використання статистичних методів обробки, наприклад, на основі згортки чисельних показників підкритеріїв визначеного кластеру. До того ж послабляється суб'єктивна складова під час оцінювання об'єктів, що порівнюються. Використовуючи математичні способи ранжування та зважування ознак, кластерний аналіз надає можливість 3 високою вірогідністю визначити схожість і відмінність об'єктів порівняння (кандидатів).

Під час проведення експерименту було запропоновано проводити процедуру оцінювання кандидатів на посаду за 100бальною шкалою. Значення інтегральної оцінки за критеріями (табл. 1) кожного кандидата, що входить до одного з визначених діапазонів оцінювання у балах, свідчить про рівень його підготовки та відповідає оцінці за 
національною шкалою оцінювання (рис. 1). ЄКТС) [13], де В - кількість балів Оцінювання проводилось по аналогії зі розподіляються у діапазонах, визначених у шкалою оцінювання Європейської кредитної табл. 2. трансферно-накопичувальної системи (далі -

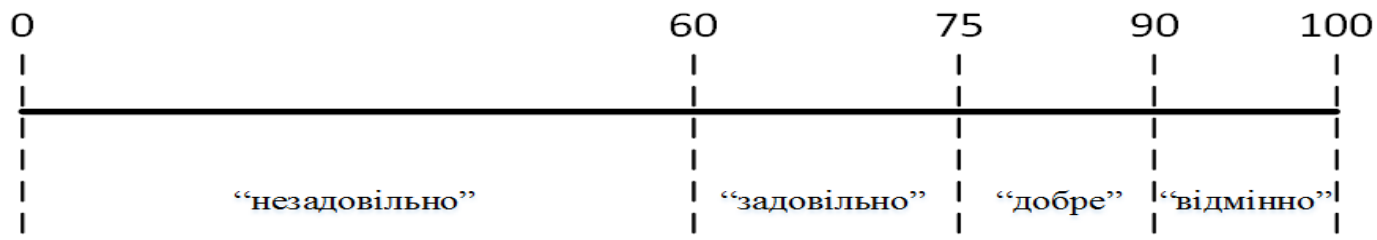

Рис. 1. Шкала оцінювання рейтингу кандидатів на посаду

Таблиця 2

\begin{tabular}{|c|c|c|}
\hline $\begin{array}{c}\text { 100-бальна шкала } \\
\text { оцінювання }\end{array}$ & $\begin{array}{c}\text { Оцінка за якісною } \\
\text { шкалою оцінювання }\end{array}$ & Пояснення \\
\hline $\mathrm{B} \geq 90$ & Відмінно & $\begin{array}{l}\text { Кандидат гідний зарахування до } \\
\text { просування по службі. }\end{array}$ \\
\hline $75 \leq \mathrm{B}<90$ & Добре & $\begin{array}{l}\text { Кандидат гідний зарахування до Резерву для } \\
\text { просування по службі; доцільно змінити характер } \\
\text { службової діяльності: продовжити службу за } \\
\text { інженерним (технічним, командним), продовжити } \\
\text { службу на посадах, пов'язаних } 3 \text { науковою та } \\
\text { педагогічною діяльністю; } \\
\text { Кандидата доцільно залишити на займаній посаді; } \\
\text { Кандидата доцільно перемістити на рівнозначну посаду }\end{array}$ \\
\hline $60 \leq \mathrm{B}<75$ & Задовільно & $\begin{array}{l}\text { Кандидата доцільно залишити на займаній посаді; } \\
\text { Кандидата доцільно перемістити на рівнозначну посаду }\end{array}$ \\
\hline$B<60$ & Незадовільно & $\begin{array}{l}\text { Кандидата доцільно перемістити на нижчу посаду; } \\
\text { Кандидата доцільно звільнити з військової служби }\end{array}$ \\
\hline
\end{tabular}

Ураховуючи факт апробації зазначеної методики оцінювання військовослужбовців для визначення їх рейтингу під час проведення експерименту у Повітряних Силах Збройних Сил України, виникла проблема щодо уточнення рейтингу в межах кожного діапазону оцінок. Це пов'язано 3 ускладненнями під час формулювання кадрового рішення по кандидатам на посади, у разі збільшення їх кількості. Кожну групу кандидатів необхідно було додатково оцінювати експертними методами.
Пропозицією, щодо підвищення об'єктивності оцінювання військовослужбовців під час формування списку резерву підготовленим особовим складом, $є$ додатковий розподіл наявних зон оцінювання на додаткові діапазони (табл. 3). Доцільність реалізації такого рішення підтверджується підвищенням швидкості обробки даних, зменшення суб'єктивізму та помилок через людський фактор.

Таблиця 3

Пропозиції щодо удосконалення шкали оцінювання кандидатів на посаду

\begin{tabular}{|c|c|c|c|}
\hline $\begin{array}{c}\text { 100-бальна шкала } \\
\text { оцінювання }\end{array}$ & \multicolumn{2}{|c|}{ Оцінка за якісною шкалою оцінювання } & Пояснення \\
\hline $\mathrm{B} \geq 95$ & \multirow{2}{*}{ Відмінно } & Тверде відмінно & $\begin{array}{l}\text { Кандидат гідний зарахування до Резерву } \\
\text { для просування по службі }\end{array}$ \\
\hline $90 \leq \mathrm{B}<95$ & & Відмінно & $\begin{array}{l}\text { Кандидата доцільно зарахувати до Резерву } \\
\text { для просування по службі }\end{array}$ \\
\hline $85 \leq \mathrm{B}<90$ & \multirow[t]{2}{*}{ Добре } & Дуже добре & $\begin{array}{l}\text { Кандидат гідний зарахування до Резерву } \\
\text { для просування по службі; доцільно } \\
\text { змінити характер службової діяльності: } \\
\text { продовжити службу за інженерним } \\
\text { (технічним, командним), продовжити } \\
\text { службу на посадах, пов'язаних з науковою } \\
\text { та педагогічною діяльністю }\end{array}$ \\
\hline $75 \leq \mathrm{B}<85$ & & Добре & $\begin{array}{l}\text { Кандидата доцільно залишити на займаній } \\
\begin{array}{l}\text { посаді; } \\
\text { Кандидата доцільно перемістити на } \\
\text { рівнозначну посаду }\end{array}\end{array}$ \\
\hline $70 \leq \mathrm{B}<75$ & \multirow{2}{*}{ Задовільно } & Задовільно & $\begin{array}{l}\text { Кандидата доцільно залишити на займаній } \\
\text { посаді }\end{array}$ \\
\hline $65 \leq \mathrm{B}<70$ & & Достатньо & $\begin{array}{l}\text { Кандидата доцільно перемістити на } \\
\text { рівнозначну посаду }\end{array}$ \\
\hline
\end{tabular}




\begin{tabular}{|c|c|c|c|}
\hline $\begin{array}{c}\text { 100-бальна шкала } \\
\text { ощінювання }\end{array}$ & \multicolumn{2}{|c|}{ Оцінка за якісною шкалою оцінювання } & Пояснення \\
\hline $60 \leq \mathrm{B}<65$ & & Слабо & $\begin{array}{lll}\text { Кандидата доцільно } \\
\text { рівнозначну посаду }\end{array}$ \\
\hline $55 \leq \mathrm{B}<60$ & \multirow{4}{*}{ Незадовільно } & Є надія & $\begin{array}{l}\text { Кандидата доцільно перемістити на нижчу } \\
\text { посаду }\end{array}$ \\
\hline $40 \leq \mathrm{B}<55$ & & Незадовільно & $\begin{array}{l}\text { Кандидата доцільно звільнити з військової } \\
\text { служби }\end{array}$ \\
\hline $20 \leq \mathrm{B}<40$ & & Дуже незадовільно & $\begin{array}{l}\text { Кандидата доцільно звільнити з військової } \\
\text { служби }\end{array}$ \\
\hline $\mathrm{B}<20$ & & Вкрай незадовільно & $\begin{array}{l}\text { Кандидата доцільно звільнити з військової } \\
\text { служби }\end{array}$ \\
\hline
\end{tabular}

На сьогодні постає питання щодо розроблення методичних рекомендації формалізації критеріїв оцінювання службової діяльності військовослужбовців, розроблення спеціального програмного забезпечення формування рейтингових списків кандидатів на посаду типової номенклатури призначення та автоматизованого формування звітності про підсумки роботи експертної комісії. Реалізація статистичної обробки даних методами кластерного аналізу в автоматизованих системах управління персоналом дасть змогу підвищити об'єктивність процесу формування рейтингу військовослужбовців, зменшити (мінімізувати) суб'єктивізм та корупційну складову під час прийняття кадрових рішень.

Висновок. Від професіоналізму, вмотивованості, патріотизму та відповідального ставлення до виконання посадових обов'язків залежить успішність виконання службових i бойових завдань особовим складом. Як показує світовий та вітчизняний досвід, досягнення цієї мети залежить від якості підбору та розстановки персоналу на посади. Левова долю успіху реалізації процедур оцінювання та рейтингування, залежить від їх об'єктивності. Серед розмаїття підходів до їх проведення, найбільший ефект досягається за допомогою застосування статистичних методів обробки багатопараметричних показників: кластерного аналізу, методу таксономії.

$$
\text { Удосконалена методика }
$$
використанням статистичних методів потребує опрацювання великої кількості вихідних даних, оперативна обробка яких потребує автоматизації процесів оцінювання та формування рейтингу кандидатів. Використання спеціального програмного забезпечення, де автоматизація зазначених процедур буде реалізована у комплексі 3 іншими взаємопов'язаними модулями, зокрема адміністрування персоналу, управління штатним розписом, ведення кваліфікацій та інші, дасть змогу в автоматизованому режимі здійснювати підбір особового складу на вакантні посади 3 урахуванням військово-облікових спеціальностей та вимог до паспорту посади.

Формування списків резерву на основі кластерного аналізу дає змогу підвищити об'єктивність процесу, швидкість обробки даних, що зменшує помилки під час обробки, внаслідок людського фактору, суб'єктивізм та корупційну складову у кадровій роботі.

Подальші дослідження доцільно зосередити на аналізі закордонного та вітчизняного досвіду використання моделей підтримки прийняття рішень для раціонального управління кар'єрою військовослужбовців, на основі бізнес-аналітичного спеціального програмного забезпечення (систем управління продуктивністю та тарсоналу) автоматизованих систем управління персоналу (управління талантами).

\section{СПИСОК ВИКОРИСТАНОЇ ЛІТЕРАТУРИ}

1. Прокопенко О. С. Особливості щорічного оцінювання, визначення рейтингу офіцерського складу та фактори, що впливають на їх об'єктивність. // Стаття. Збірник наукових праць ЦВСД НУОУ ім. І. Черняховського. - № 2 (51). 2014 p. C. 71-75. ISSN 2304-2699.

2. Рибидайло А. А. Аналіз досвіду провідних країн світу щодо формування та використання кадрового резерву у збройних силах/ Турейчук А.М., Прокопенко О.С./ Київ ЦВСД НУОУ, Збірник наукових праць, № 2 (60). - 2017 р. С. 121-129. ISSN 2304-2699.

3. Рибидайло А.А. Формування дієвого резерву кандидатів для просування по службі та його використання під час підготовки $\mathrm{i}$ прийняття кадрових рішень/ Турейчук А. М., Прокопенко О. С., Дергильова О. В./ Київ : ЦВСД НУОУ, Збірник наукових праць, № 3 (61). 2017 p. C. 67-74. ISSN 2304-2699.

4. Прокопенко О. С. Варіант побудови рейтингу військовослужбовців на основі таксономічного аналізу. / Рибидайло А. А., Турейчук А. М., Комолаєва Т. М. // Стаття. Збірник наукових праць ЦВСД НУОУ ім. І. Черняховського. - К : № 3 (61). - 2017p. C. 109-113. ISSN 2304-2699.

5. Перелік підкритеріїв до критеріїв оцінки службової діяльності військовослужбовців за типами посад //Військовий інститут Київського національного університету імені Тараса 
Шевченка / За ред. В.В.Балабіна. - К.: НКК ВІ КНУ, 2010. - 342 c.

6. Методичні рекомендації з порядку формування i використання Резерву кандидатів для просування по службі у Збройних Силах України, затверджені директором Департаменту кадрової політики Міністерства оборони України від 19.03.2018 № 350 .

7. Методичні рекомендації з порядку організації і проведення атестування військовослужбовців Збройних Сил України, затверджені директором Департаменту кадрової політики Міністерства оборони України від 12.10.2018 № 226/4907.

8. Виноградський М. Д. Управління Персоналом. / Виноградська А. М., Шканова О. М. // 2-ге видання.: Навчальний посібник. - К. : центр учбової літератури, 2009. - 502 с. ISBN 978-966364-766-1.

9. Організація забезпечення органів управління військами (силами) : Підручник / [Ю.Г. Даник, С. А. Микусь, В. Г. Солонніков, В. О. Крайнов та ін.].- К.:НУОУ ім. І. Черняховського, 2019. - 237 c.

10. Соколова Л. В. Використання методів кластерного аналізу у практичній діяльності підприємств. / Г. М. Верясова, О. Є. Соколов. [електронний ресурс]. / режим доступу: http://ena.lp.edu.ua:8080/bitstream/ntb/ 13865/1/ 37_240-246_Vis_720_Menegment.pdf.

11. Ким О. Дж. Факторный, дискриминантный и кластерный анализ. / Мьюллер Ч. У., Клекка У. Р., и др Под ред. И. С. Енюкова. - М. : Финансы и статистика, 1989. - 215 с:
12. Методичні рекомендації з порядку визначення рейтингу військовослужбовців Збройних Сил України, затверджені директором Департаменту кадрової політики Міністерства оборони України від 29.12.2009 № 226/1/4545.

13. Наказ Міністра оборони України від 20.07.2015 № 346 “Про затвердження Положення про особливості організації освітнього процесу у вищих військових навчальних закладах Міністерства оборони України та військових навчальних підрозділах вищих навчальних закладів України".

14. План дій щодо впровадження оборонної реформи у 2016 - 2020 роках (дорожня карта оборонної реформи), затверджений Міністром оборони України від 15.08.2016. // [електронний ресурс]./ режим доступу: http://www.mil.gov.ua/content/tenders/Plan_2208.pdf

15. Концепція військової кадрової політики у Збройних Силах України на період до 2020 року, затверджена наказом Міністерства оборони України № 342 від 26.06.2017 р. // [електронний pecypc]./ режим доступу: http://www.mil.gov.ua/ diyalnist/kadrova-politika/konczepcziya-kadrovoipolitiki-v-zbrojnih-silah-ukraini/.

16. План проведення в Повітряних Силах Збройних Сил України у 2018 році експерименту зі створення сучасної системи кадрового менеджменту, затвердженого наказом Генерального штабу Збройних Сил України від 14.02.2018 p. №79.

Стаття надійшла до редакційної колегії 05.02.2019

Думенко Н. П., к.воен.н. ${ }^{1}$;

Прокопенко А. C. ${ }^{2}$

1 - Главное управление персонала Генерального штаба Вооружённых Сил Украины, Киев;

2 - Центр военно-стратегических исследований Национального университета обороны Украины имени Ивана Черняховського, Киев

\section{вакантную должность \\ Методика формирования резерва кандидатов для назначения на определенную}

Резюме. В статье рассмотрены вопросы комплектования вооруженных сил подготовленным личным составом за счет использования резерва. Резерв формируется на базе рейтинга военнослужащих в виде рейтингового списка. Усовершенствована методика формирования рейтингового списка.

Ключевые слова: комплектование вооруженных сил подготовленным личным составом; кадровый резерв; оценка военнослужащего; рейтинговый список; список кандидатов к назначению на определенную должность.

\section{N. Dumenko, PhD (Military) ${ }^{1}$; \\ O. Prokopenko ${ }^{2}$}

${ }^{1}$ - Main Personnel Directorate of the General Staff of the Armed Forces of Ukraine, Kyiv;

2 - Center for Military and Strategic Studies of the National Defence University of Ukraine named after Ivan Cherniakhovskyi, Kyiv

\section{Methods of forming a reserve of candidates for appointment to a specific vacant position}

Resume. The article addresses the issues of staffing the armed forces with trained personnel through the use of a reserve. The reserve is formed on the basis of the rating of servicemen in the form of a rating list. The method of forming a rating list has been improved.

Keywords: staffing the armed forces with trained personnel; personnel reserve; assessment of the soldier; rating list; list of candidates for appointment to a certain position. 